\title{
Internet Usage, Challenges, and Attitudes among University Students: Case Study of the University of Jordan
}

\author{
Tamara Almarabeh, Yousef Kh. Majdalawi, Hiba Mohammad \\ Computer Information Systems Department, The University of Jordan, Amman, Jordan \\ Email:t.almaraabeh@ju.edu.jo,ymajdal@ju.edu.jo,h.khadrawi@ju.edu.jo
}

How to cite this paper: Almarabeh, T., Majdalawi, Y.Kh. and Mohammad, $\mathrm{H}$. (2016) Internet Usage, Challenges, and Attitudes among University Students: Case Study of the University of Jordan. Journal ot Software Engineering and Applications, 9, 577-587.

http://dx.doi.org/10.4236/jsea.2016.912039

Received: October 5, 2016

Accepted: December 6, 2016

Published: December 9, 2016

Copyright $\odot 2016$ by authors and Scientific Research Publishing Inc. This work is licensed under the Creative Commons Attribution International License (CC BY 4.0).

http://creativecommons.org/licenses/by/4.0/

\begin{abstract}
The Internet usage has grown rapidly during the last decade in almost every country in the world and in Jordan specifically; today millions of individuals are connected to the Internet and the Internet has become the backbone of the information economy. It was used for social, commercial, political, and personal interactions. This study aims to investigate the attitudes of students at The University of Jordan towards using ICT (Information and Communication Technology). A semi-structured questionnaire was used to collect the data for obtaining students attitudes on the amount of Internet usage, reasons for using the Internet, and how the Internet impacted on students' life. The data analysis was done by using SPSS, version 17. 536 students from different faculties (medical, humanities, and scientific) of the University of Jordan participated in the study. The results indicated that most students access Internet before they attended university; there is a positive attitude towards Internet; and they used it mainly for social websites, chatting and information gathering. The slow speed of the Internet connection and the lack of adopting ICT in courses syllabus are some constraints facing the students.
\end{abstract}

\section{Keywords}

ICT, Jordan, Internet, Attitudes, Literacy, Higher Education

\section{Introduction}

The Internet is a global system of connections that links millions of people publicly [1]. The Internet enables individuals and businesses to interact and share information, resources, and services [2].

The use of the Internet is an important tool in higher education [3] where the Inter- 
net has become a helpful source for students to get information [4]. Today, there is a huge number of learning materials embedded in the Internet and the students can get a quick access to the information [5].

Online applications which are available to the college students can enhance the quality of education [6] [7]. Many scholars agree that Information and Communication Technology (ICT) plays an increasingly important role in facilitating the educational systems [8] [9] [10].

According to the Internet World Stats in June 2016, the number of Internet users in Jordan approximately equals 5,700,000 (73.6\% of Jordanian population). The awareness of Internet importance in Jordan has risen in different regions such as education. By a variety of measures, Internet is an essential part of almost college student's life [11].

Internet usage and developments in technology growth around the world have grown rapidly and changed the lives of millions of people during the last decade [12] [13]. Internationally, there have been many researches on the Internet usage and most of them found that the Internet usage is most prevalent among younger and more educated people for students and teachers; the Internet is becoming an increasingly important part of the educational process in a classroom and in a textbook [14].

M. Yilmaz and Feza Orhana [15] studied 921 secondary school students and Learning Process Questionnaire (LPQ) was used. According to the data obtained, the researchers examined that the ratios of the Internet usage for educational purposes for deep learning and by the students who are given assignments by the Internet are higher when compared to the surface learners. In a survey of Internet usage of the students in the University of the Punjab, Lahore, Pakistan, Basir et al. [16] reported that ease of working and time savings are the reasons of Internet use among students.

Camilla Brändström [17] studied data from five upper secondary school teachers through face-to-face interview, where the researcher found that the teachers think that the Internet is a valuable teaching tool which can increase the motivation of the students, make teaching more enjoyable, and allow variation in teaching. The drawbacks of the Internet usage are students' cheating, unreliable information, technical problems, and students' extracurricular activities during lessons. The Internet can affect a student's academic performance in both positive and negative way so that we need to control Internet usage which can have positive influence on student's academic performance [11].

The Internet can be used by individuals and families as a communication way [18]. People use social media networks, and in particular, college students represent a large proportion of users on social media networks to communicate with friends. Lenhart et al. [19] found that $72 \%$ of all college students have a social media profile. The survey was conducted by Princeton Survey Research Associates International and the interviews were done in English by Princeton Data Source, LLC from June 26 to September 24, 2009.

Many researchers found that the college students use Internet for sending/receiving e-mails, chatting, gathering information, downloading music or images, and playing 
games.

This paper presents an overview of 536 undergraduate students' attitudes towards ICT at the University of Jordan based on an online survey through exploring their Internet usage behavior, how much they frequently use Internet, the most Internet services they use, why they use Internet, and the problems they face during using Internet.

The structure of this paper is organized as follows: Section 2 provides the methodology and the limitations of the research. Discussion and Results are in Section 3 with charts and percentages. Finally, the conclusion is in Section 4.

\section{Methodology and Limitations}

The present study was carried out at the University of Jordan among the undergraduate students of the medical, scientific, and humanities faculties, which included male and female students, who registered in three compulsory computer skills courses: Remedial computer skills, Computer Skills for Humanities, and Computer Skills for Medical Students during Fall Semester 2016-2017. The collected data were analyzed and presented in the form of tables and charts and the results were reported in percentages. The aim of this study is to identify the basic skills of the students at The University of Jordan in using computer and Internet. A semi-structured questionnaire filled by 536 students was used for data collection where the questions were adopted from previous researches [20] [21] [22] [23] [24] [25] with modifications. The questions were divided in two categories; the first category contains the students' demographics which are shown in Table 1. The second category contains 9 questions spread over 3 sections:

1) The University of Jordan students' usage of ICT. 2) Constraints in using ICT at The University of Jordan and 3) Students' attitudes toward ICT

However, the study has the following limitations:

$\checkmark$ The study is limited to one public university, which is The University of Jordan.

$\checkmark$ The study includes only the undergraduate students at The University of Jordan.

\section{Discussion and Results}

It was observed that majority of the students' were females 382 (71\%) while 154 (29\%) were males. The distribution of the faculties shows that major of the students came from humanities faculties with 292 (54\%) and the least is from Medical faculties with 90 (17\%), this returns for two reasons; first: a few medical students failed in the computer competency exam, and enroll in Remedial computer Skills course. Second: the teaching System for the Faculty of Medicine and faculty of dentistry is year's system not credit hour's system and computer skills for medical students course is scheduled for the spring semester and this study was conducted during the fall semester. It was observed that majority $93 \%$ of the students started using computer and Internet before joining the university while 7\% started after joining it. $230(43 \%)$ have been using Internet for 6 years and more followed by 154 (29\%) have been using it for 4 - 5 year, while 103 (19\%) of the students have been using it for $2-3$ years and 49 (9\%) of them have been using it 
Table 1. Students' demographics.

\begin{tabular}{cccc}
\hline Category & Characteristics & Number & Percentage \\
\hline \multirow{2}{*}{ Gender } & Male & 154 & $29 \%$ \\
& Female & 382 & $71 \%$ \\
\hline Excellent & 108 & $20 \%$ \\
Very good & Good & 198 & $37 \%$ \\
& Fair & 154 & $29 \%$ \\
Type of Faculty & Medical & 76 & $14 \%$ \\
\hline Scientific & 90 & $17 \%$ \\
Cirst Use of & Humanities & 154 & $29 \%$ \\
\hline Computer? & Before joining the university & 292 & $54 \%$ \\
\hline After joining the university & 496 & $93 \%$ \\
& 0 - 1 year & 40 & $7 \%$ \\
\hline & $2-3$ year & 49 & $9 \%$ \\
\hline & $4-5$ year & 103 & $19 \%$ \\
\hline & $6+$ years & 154 & $29 \%$ \\
\hline
\end{tabular}

for less than 1 year as shown in Table 1. The findings were in line with the surveyed of Kumar and Kaur [26] as well as that of Salako and Tiamiyu [27] which indicated that the students have the experience. Also this agrees with Bankole and Babalola [28] that $34.8 \%$ of undergraduate students have been using the Internet from $5-6$ years. Similarly, Fasae and Aladeniyi [29] who reported that $65 \%$ had more than 3 years Internet experience.

1) The University of Jordan Students' Use of ICT

Information and Communication Technology (ICT) has brought about a revolution in every walk of today's life. Particularly it has become an integral part of education and no one can deny its impact on teaching and learning. ICT plays a key role in the development of any country. ICT is a general term which includes computers, the Internet, and electronic delivery systems such as radios, televisions, and projectors ...etc.

Using computer and Internet is greatly depending on some factors such as: Students' experience, Internet purposes, facilities, and available services ...etc. This part was analyzing these factors for The University of Jordan students.

When evaluating the students' literacy of using computer and Internet, $73 \%$ of the students considered as an average user. 10\% considered themselves as beginners and $13 \%$ as experts. Few of them (4\%) are unfamiliar with using computer and Internet as you see in Figure 1.

Students were asked to indicate how often they use Internet. Figure 2 shows that 437 $(82 \%)$ of the students use Internet daily while $99(18 \%)$ use it weekly. The findings agree with Ani [30] study on Internet access and use. Similarly, Awoleye et al. [31] 


\section{Skills in Using Computer and Internet}

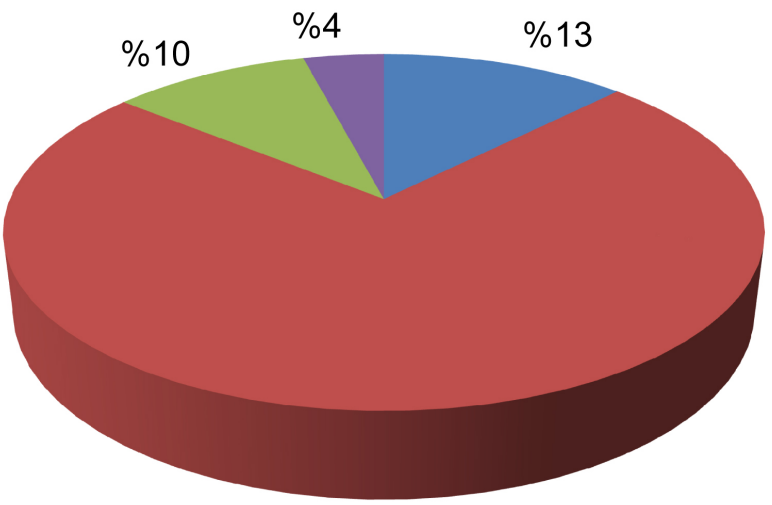

$\% 73$

Figure 1. Skills in using computer and Internet.

\section{Frequency of Using Internet}

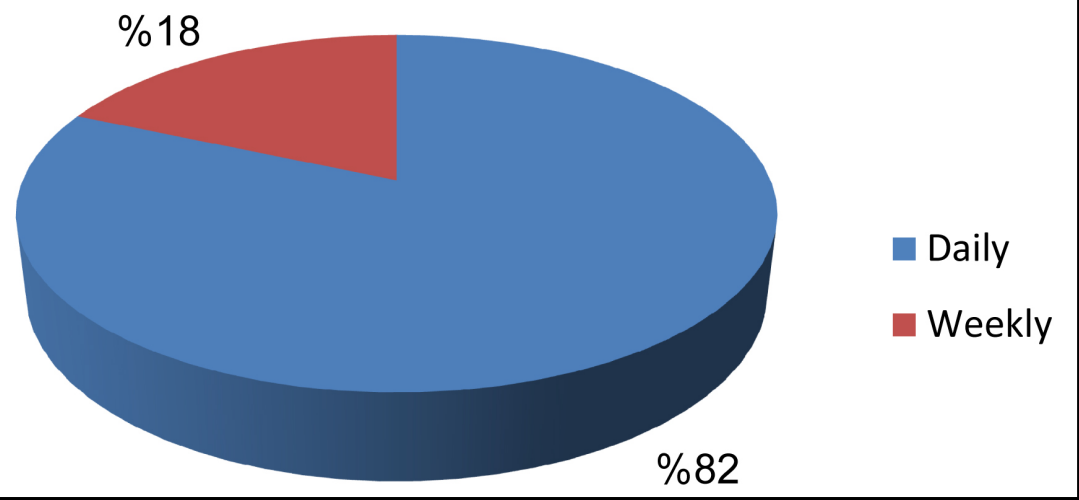

Figure 2. Frequency of Internet use.

study shows that about $92 \%$ of undergraduate students have embraced the Internet and are using it consistently.

Table 2 summarizes the purpose of using Internet at The University of Jordan. One other significant trend emerged from the results is the increased perceived importance of social media as one of the attractive features of the Internet. This finding is consistent with the finding of Pempek et al. [32] who found the use of social networking sites has become part of daily lives students around the globe.

Communication, entertainment, academic studies and research, and software downloading were also mentioned as an important usage of Internet by students. This finding is consistent with the finding of [33] [34] [35] [36] [37]. Very few students used Internet to purchase items. One possible explanation is that these students do not have 
Table 2. Purposes of using Internet.

\begin{tabular}{|c|c|c|c|}
\hline Number & Purposes of using Internet & Frequency & Percentage \\
\hline 1 & $\begin{array}{l}\text { Using Internet for social networking websites } \\
\text { (i.e. face book, twitter, etc.) }\end{array}$ & 525 & $97.95 \%$ \\
\hline 2 & Using Internet for chatting with friend (Messenger) & 514 & $95.90 \%$ \\
\hline 3 & $\begin{array}{l}\text { Using Internet for studying, information gathering, } \\
\text { and searching }\end{array}$ & 493 & $91.98 \%$ \\
\hline 4 & $\begin{array}{l}\text { Using Internet for watching or downloading } \\
\text { songs and videos }\end{array}$ & 458 & $85.45 \%$ \\
\hline 5 & Using Internet for reading news & 453 & $84.51 \%$ \\
\hline 6 & Using Internet for mailing & 423 & $78.92 \%$ \\
\hline 7 & Using Internet for playing games & 343 & $63.99 \%$ \\
\hline 8 & Using Internet for buying products online & 195 & $36.38 \%$ \\
\hline
\end{tabular}

enough financial resources at their own to make purchases online.

The preferred resource for getting information among the students in the present study was the Internet with percentage (35\%), then followed by textbooks (34) as shown in Figure 3. This indicates the high awareness of using Internet for getting the required information.

The students were asked to mention the reasons for using Internet. Figure 4 shows the distribution of the students' responses. Consistent with the findings of [16] [38], The University of Jordan students still regard Internet as a tool that provide time saving (37\%) and easy accessibility (30\%).

The present study revealed that the social media websites are the most common accessed websites (51\%) where this result agrees with Table 1, followed by Google as in Figure 5.

When asking the students if they are confident for using the MS office applications. 91.42\% used MS-Word; this is natural result because all the faculties' students are required to do assignments on MS-Word. 74.07\% of the students used MS-Power Point software for preparing presentations, then MS-Excel as shown in Table 3. Lecturers need to activate working on MS-Excel through assignments.

2) Constraints of Using ICT at The University of Jordan

Table 4 shows the constraints and the limitations of the Internet usage at The University of Jordan. The major constraint was the slow speed of Internet as indicated by (62.31\%) of 536 students. The other main constraint is not adopting ICT in the courses syllabuses (46.83\%). Bankole and Babalola [28] their finding also shows that slowness of the server is one of the major constraints facing Internet usage among Olabisi Onabanjo undergraduate students. Fasae and Aladeniyi [29] also found that $96 \%$ indicated slow access speed as the leading problem.

\section{Students' Attitudes toward ICT}

The analysis of data on 7 statements used to access The University of Jordan students' 


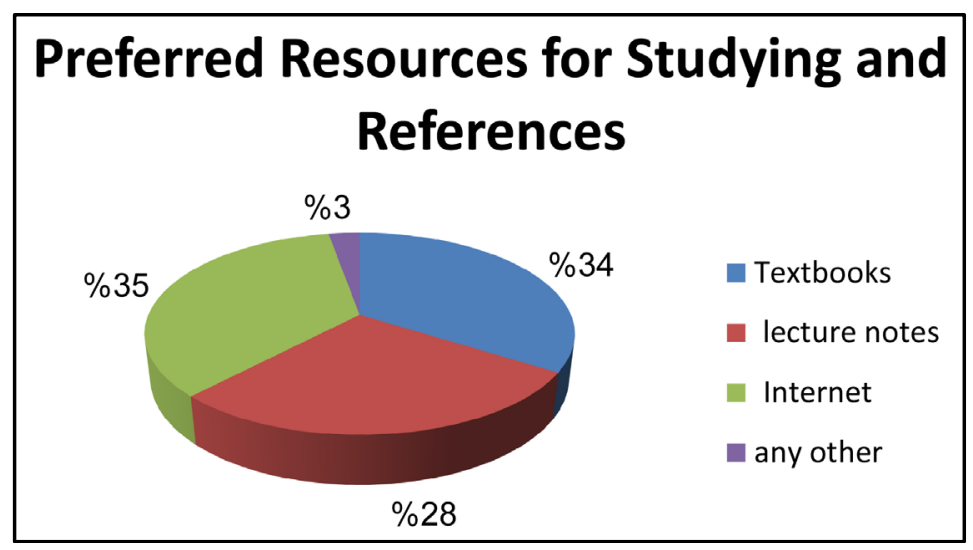

Figure 3. Preferred resources for studying and references.

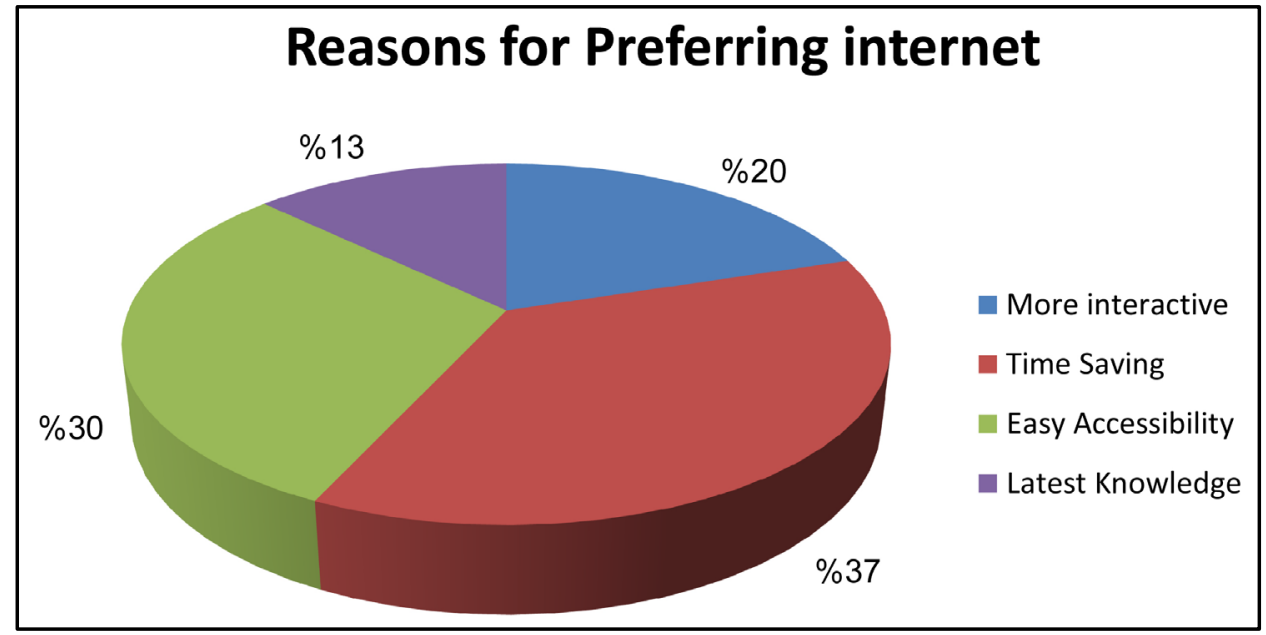

Figure 4. Advantages of using Internet.

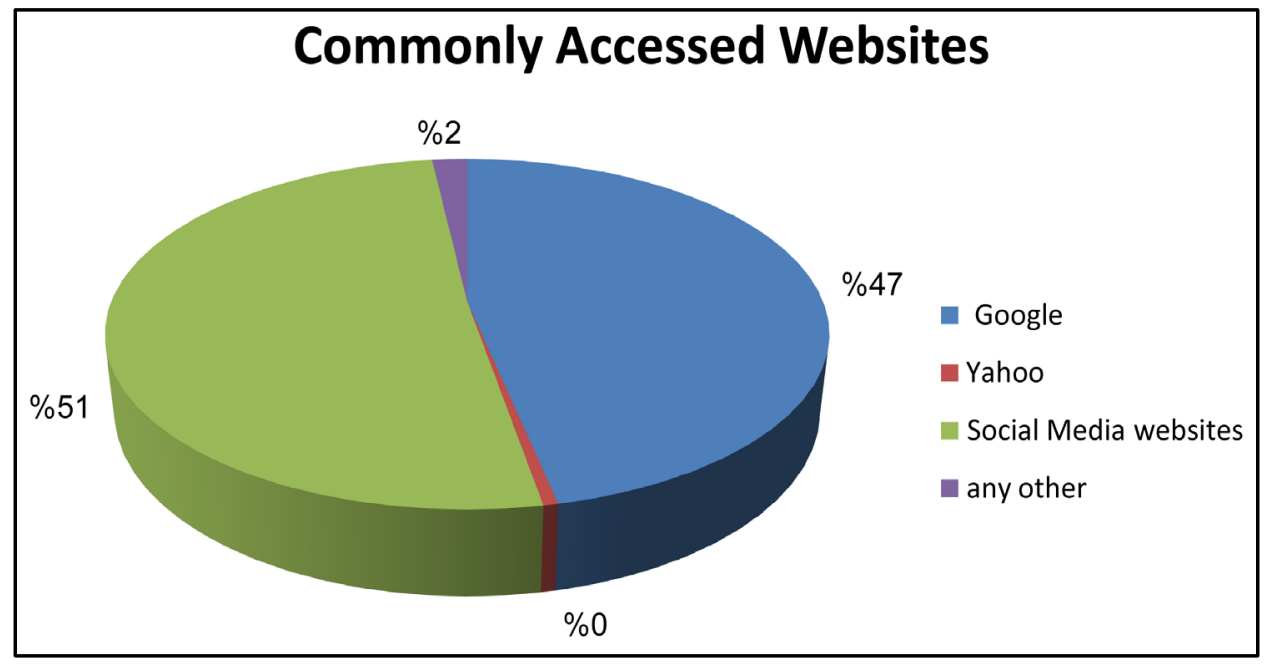

Figure 5. Commonly accessed websites.

attitudes toward ICT as presented in Table 5 which reveals that overall attitudes of the 
students are positive.

The researchers in Table 6 compared some of this study results with other studies to determine the status of the University of Jordan students in this study with previous studies.

\section{Conclusion}

The current study evaluated the awareness and utilization of ICT among the students at the University of Jordan. The researchers for this paper recommended that the academics and decision makers at the University of Jordan pay more attentions in planning, developing, and implementing ICT strategies because the ICT is an important tool in higher education and in the college student's life, and redirect the student to

Table 3. Working on MS-Office applications.

\begin{tabular}{cccc}
\hline Number & Purposes of using Internet & Frequency & Percentage \\
\hline 1 & Do you work on MS-Word application? & 490 & $91.42 \%$ \\
2 & Do you work on MS-Power point application? & 397 & $74.07 \%$ \\
3 & Do you work on MS-Excel application? & 294 & $54.85 \%$ \\
\hline
\end{tabular}

Table 4. Constraints of using Internet at the University of Jordan.

\begin{tabular}{cccc}
\hline Number & Constraint of using Internet & Frequency & Percentage \\
\hline 1 & Slow speed on Internet & 334 & $62.31 \%$ \\
2 & ICT not adapted in my courses syllabuses & 251 & $46.83 \%$ \\
3 & Inadequate computers in labs & 248 & $46.27 \%$ \\
4 & Payment restriction for Important information I need & 224 & $41.79 \%$ \\
5 & Difficulty in finding relevant information & 195 & $36.38 \%$ \\
7 & lack of knowledge about searching (advanced searching) & 177 & $33.02 \%$ \\
\hline
\end{tabular}

Table 5. Constraints of using Internet at the University of Jordan.

\begin{tabular}{cccc}
\hline Number & Attitude & Frequency & Percentage \\
\hline 1 & Using ICT allows me to get more information & 522 & $97.39 \%$ \\
2 & Using ICT improve communication & 514 & $95.90 \%$ \\
3 & Using ICT allows me to saving time and efforts & 512 & $95.52 \%$ \\
4 & Using ICT provide multiple of services & 506 & $94.40 \%$ \\
5 & Using ICT important for studying materials & 494 & $92.16 \%$ \\
6 & Using ICT facilitate obtaining learning material & & \\
7 & (e-books, up to date information) & 484 & $90.30 \%$ \\
\hline
\end{tabular}


Table 6. Comparison between present study and other studies.

\begin{tabular}{cccc}
\hline Studies & $\begin{array}{c}\text { Use of the search } \\
\text { Engine Google }\end{array}$ & $\begin{array}{c}\text { Academic purpose of } \\
\text { Internet }\end{array}$ & $\begin{array}{c}\text { Difficulties in } \\
\text { using Internet } \\
\text { (slow speed) }\end{array}$ \\
\hline $\begin{array}{c}\text { Present Study } \\
\text { (The University of Jordan) } \\
\text { Khan et al. [23] }\end{array}$ & $47 \%$ & $91.98 \%$ & $62.31 \%$ \\
Fasaeand Aladeniyi [29] & $83 \%$ & $78 \%$ & $80 \%$ \\
Amaoge and Ejike [39] & - & $89 \%$ & $96 \%$ \\
Manzoor [40] & - & $52.7 \%$ & $25.9 \%$ \\
Adekunmisi et al. [41] & $95 \%$ & $88.3 \%$ & - \\
\hline
\end{tabular}

positive attitudes in using Internet.

\section{Acknowledgements}

The authors would like to thank all The University of Jordan students who participated in this study and acknowledge the immense help which was received from the scholars whose articles have been cited and included among the references.

\section{References}

[1] Ruzgar, N.S. (2005) A Research on the Purpose of Internet Usage and Learning via Internet. The Turkish Online Journal of Educational Technology, 4, 27-32.

[2] Dogruer, N., Eyyam, R. and Menevis, I. (2011) The Use of the Internet for Educational Purposes. Procedia-Social and Behavioral Sciences, 28, 606-611. https://doi.org/10.1016/j.sbspro.2011.11.115

[3] Sahin, Y.G. (2010) The Use of Internet Resources by University Students during Their Course Projects Elicitation: A Case Study. The Turkish Online Journal of Educational Technology, 9, 234-244.

[4] Aduwa-Ogiegbaen, S.E. and Iyamu, E.O.S. (2005) Using Information and Communication Technology in Secondary Schools in Nigeria: Problems and Prospects. Educational Technology \& Society, 8, 104-112.

[5] Alshammari, N. (2014) The Use of Technology in Education to Improve Student's Reading Skills in Elementary Schools, Saudi Arabia. International Journal of Business and Social Science, 5, 69.

[6] O’Donoghue, J., Singh, G. and Green, C. (2004) A Comparison of the Advantages and Disadvantages of IT Based Education and the Implications upon Students. Interactive Educational Multimedia, 9, 63-76.

[7] Al-Adwan, A. and Smedley, J. (2012) Implementing E-Learning in the Jordanian Higher Education System: Factors Affecting Impact. International Journal of Education and Development Using Information and Communication Technology (IJEDICT), 8, 121-135.

[8] Al-Hunaiyyan, A., Al-Huwail, N. and Al-Sharhan, S. (2008) Blended E-Learning Design: Discussion of Cultural Issues. International Journal of Cyber Society and Education, 1, 1732.

[9] Oh, E. and Park, S. (2009) How Are Universities Involved in Blended Instruction? Educa- 
tional Technology \& Society, 12, 327-342.

[10] Vaughan, N. and Garrison, R. (2006) A Blended Faculty Community of Inquiry: Linking Leadership, Course Redesign, and Evaluation. Canadian Journal of University Continuing Education, 32, 67-92.

[11] Ellore, S., Niranjan, S. and Brown, U.J. (2014) The Influence of Internet Usage on Academic Performance and Face-to-Face Communication. Journal of Psychology and Behavioral Science, 2, 163-186.

[12] Kolodziejczyk, I. (2009) ICT for Education-The Way Ahead, but How? Contemporary PNG Studies: DWU Research Journal, 11, 31-33.

[13] Lavin, A., Korte, L. and Davies, T.L. (2010) The Impact of Classroom Technology on Student Behavior. Journal of Technology Research, 2, 1.

[14] Carmona, M. (2013) ICT Trends in Education. 1st Annual International Interdisciplinary Conference, Azores, 24-26 April 2013, 428-430.

[15] Betül, M., Õlmaza, Y. and Orhana, F. (2010) The Use of Internet by High School Students for Educational Purposes in Respect to Their Learning Approaches. Procedia-Social and Behavioral Sciences, 2, 2143-2150. https://doi.org/10.1016/j.sbspro.2010.03.296

[16] Bashir, S., Mahmood, K. and Shafiq, F. (2008) Internet Use among University Students: A Survey in University of the Punjab, Lahore. Pakistan Journal of Library \& Information Science, 9, 49-65. http://eprints.rclis.org/19027/

[17] Brändström, C. (2011) Using the Internet in Education-Strengths and Weaknesses. A Qualitative Study of Teachers. Opinions on the Use of the Internet in Planning and Instruction, University of Gävle, Gävle. http://www.diva-portal.org/smash/get/diva2:438827/FULLTEXT01.pdf

[18] Sponcil, M. and Gitimu, P. (2013) Use of Social Media by College Students: Relationship to Communication and Self-Concept. Journal of Technology Research, 4, 1-13.

[19] Lenhart, A., Purcell, L., Smith, A. and Zickuhr, K. (2010) Social Media and Young Adults. Pew Internet and American Life Project. http://www.pewinternet.org/Reports/2010/Social-Media-and-Young-Adults.aspx

[20] Hamissi, J., Gholami, S. and Hamissi, H. (2012) Evaluation of Information and Communication Technology Knowledge among Undergraduate Dental Students in Iran. Asian Journal of Computer Science and Information Technology, 8, 247-250.

[21] Challa, N. and Madras, V. (2014) Attitude, Awareness and Usage Skills of Computer and Internet among Medical Students. IOSR Journal of Dental and Medical Sciences, 13, 24-27. https://doi.org/10.9790/0853-13542427

[22] Aldebasi, Y. and Ahmed, M.I. (2013) Computer and Internet Utilization among the Medical Students in Qassim University, Saudi Arabia. Journal of Clinical and Diagnostic Research, 7, 1105-1108. https://doi.org/10.7860/jcdr/2013/5891.3092

[23] Khan, S.A., Khan, A.A. and Bhatti, R. (2011) Internet Access, Use and Gratification among University Students: A Case Study of the Islamia University of Bahawalpur, Pakistan. Chinese Librarianship, 32, 1-14.

[24] Mahmood, K. (2009) Gender, Subject and Degree Differences in University Students' Access, Use and Attitudes toward Information and Communication Technology (ICT). International Journal of Education and Development using Information and Communication Technology, 5, 206-216.

[25] Aderonke, O. and Mrs, O. (2013) Internet Access and Use among Undergraduate Students of Bowen University Iwo, Osun State, Nigeria. Library Philosophy and Practice (E-Journal), Paper 964. http://digitalcommons.unl.edu/libphilprac/964 
[26] Kumar, R. and Kaur, A. (2005) Internet and Its Use in the Engineering College of Punjab, India: A Case Study. Webology, 2, 1-18. http://www.webology.org/2005/v2n4/a21.html

[27] Salako, O.A. and Tiamiju, M.A. (2007) Use of Search Engines for Research by Postgraduate Students of the University of Ibadan, Nigeria. African Journal of Library, Achieves and Information Science, 7, 103-115.

[28] Bankole, O.M. and Oludayo, B.S. (2012) Internet Use among Undergraduate Students of Olabisi Onabanjo University Ago-Iwoye, Nigeria. Library Philosophy and Practice. http://digitalcommons.unl.edu/libphilprac/812

[29] Fasae, J.K. and Aladeniyi, F.R. (2012) Internet Use by Students of Faculty of Science in Two Nigerian Universities. Library Philosophy and Practice. http://unllib.unl.edu/LPP/

[30] Ani, O.E. (2010) Internet Access and Use: A Study of Undergraduate Students in Three Nigerian Universities. Electronic Library, 28, 555-567.

http://www.emeraldinsight.com/journals.htm?articleid $=1878368$ https://doi.org/10.1108/02640471011065373

[31] Awoleye, O.M., Siyanbola, W.O. and Oladipo, O.F. (2008) Adoption Assessment of Internet Usage amongst Undergraduates in Nigeria Universities-A Case Study Approach. Journal of Technology Management and innovation, 3, 84-89. http://www.jotmi.org

[32] Pempek, T.A., Yermolayeva, Y.A. and Calvert, S.L. (2009) College Students' Social Networking Experiences on Facebook. Journal of Applied Developmental Psychology, 30, 227238. https://doi.org/10.1016/j.appdev.2008.12.010

[33] Baker, R.K. and White, K.M. (2010) In Their Own Words: Why Teenagers Don't Use Social Networking Sites. Cyberpsychology, Behavior, and Social Networking, 14, 395-398. https://doi.org/10.1089/cyber.2010.0016

[34] Cheung, C.M.K., Chiu, P.-Y. and Lee, M.K.O. (2011) Online Social Networks: Why Do Students Use Facebook? Computers in Human Behavior, 27, 1337-1343. https://doi.org/10.1016/j.chb.2010.07.028

[35] Roblyer, M.D., McDaniel, M., Webb, M., Herman, J. and Witty, J.V. (2010) Findings on Facebook in Higher Education: A Comparison of College Faculty and Student Uses and Perceptions of Social Networking Sites. The Internet and Higher Education, 13, 134-140. https://doi.org/10.1016/j.iheduc.2010.03.002

[36] Bosch, T.E. (2009) Using Online Social Networking for Teaching and Learning: Facebook Use at the University of Cape Town. Communication, 35, 185-200. https://doi.org/10.1080/02500160903250648

[37] Richardson, K. and Hessey, S. (2009) Archiving the Self? Facebook as Biography of Social and Relational Memory. Journal of Information, Communication and Ethics in Society, 7, 25-38. https://doi.org/10.1108/14779960910938070

[38] Muniandy, B. (2010) Academic Use of Internet among Undergraduate Students: A Preliminary Case Study in a Malaysian University. International Journal of Cyber Society and Education, 3, 171-178.

[39] Amaoge, D.A. and Ejike, U.I. (2016) Assessment of Internet Awareness and Use by the Undergraduate Students of College of Agricultural and Science Education in Michael Okpara University of Agriculture Umudike. American Journal of Educational Research, 4, 200-203.

[40] Manzoor, A. (2014) Behavioral Pattern of Internet Use among University Students of Pakistan. International Journal of Computer Science and Business Informatics, 14, 25-36.

[41] Adekunmisi, S.R., Ajala, E.B. and Iyoro, A.O. (2013) Internet Access and Usage by Undergraduate Students: A Case Study of Olabisi Onabanjo University, Nigeria. Library Philosophy and Practice (E-Journal), Paper 848. 
Submit or recommend next manuscript to SCIRP and we will provide best service for you:

Accepting pre-submission inquiries through Email, Facebook, LinkedIn, Twitter, etc.

A wide selection of journals (inclusive of 9 subjects, more than 200 journals)

Providing 24-hour high-quality service

User-friendly online submission system

Fair and swift peer-review system

Efficient typesetting and proofreading procedure

Display of the result of downloads and visits, as well as the number of cited articles

Maximum dissemination of your research work

Submit your manuscript at: http://papersubmission.scirp.org/

Or contact jsea@scirp.org 